\title{
Dilema Demokrasi Liberal: Hambatan Normatif, Institusional dan Praktikal dalam Pemberlakuan Kuota Perempuan di Indonesia
}

\section{Nur Azizah}

Jurusan IImu Hubungan Internasional, Fakultas IImu Sosial dan IImu Politik, Universitas Muhammadiyah Yogyakarta

Ringroad Barat Tamantirto, Kasihan, Bantul 55183

Email: nurazizah@umy.ac.id

\begin{abstract}
Political reform in 1998 Indonesia brought an inclusive participation to all people. One of its significant outcomes was the establishment of women quota that tried to accommodate women's aspirations in Indonesian democratic system, particularly in the parliament. This policy had been legalized in the constitution article 65 UU 122003 about General Election of the House of Representative which then finalized in 2008. However, this quota mechanism has many barriers in its implementation such as from Mahkamah Konstitusi that decided to change the instrument for elected candidate which based not on the consecutive number, so the quota system was complicated to put into practice. This article tries to explain why the performance of women quota was ineffective. To address the problems, analysis of this article based on feminist perspective with critical discourse of analysis (CDA). The study will be conducted on three levels namely normative level, institutional level, and practical level. Keywords: liberal democracy, women quota, participation, Indonesia

Abstrak

Reformasi politik Indonesia pada 1998 membawa partisipasi inklusif bagi semua orang. Salah satu hasil signifikannya adalah pembuatan kuota perempuan yang dicoba untuk mengakomodasi aspirasi perempuan di dalam sistem demokrasi Indonesia., khususnya di parlemen. Kebijakan ini disahkan dalam undang-undang Artikel 65 UU 122003 mengenai Pemilihan Umum DPR yang kemudian diselesaikan pada 2008. Namun, mekanisme kuota memiliki banyak hambatan dalam pelaksanaannya seperti Mahkamah Konstitusi yang memutuskan mengubah instrumen calon terpilih tidak berdasarkan nomor urut, sehingga sistem kuota menjadi rumit untuk dipraktikkan. Artikel ini mencoba menjelaskan mengapa kinerja kuota perempuan tidak efektif. Untuk mengatasi masalah ini, analisa artikel didasarkan pada perspektif feminis dengan diskursus kritis analisis (CDA). Penelitian ini akan dilakukan pada tiga tingkatan, yaitu tingkat normatif, tingkat institutional, dan tingkat praktik.

Kata kunci: demokrasi liberal, kuota perempuan, partisipasi, Indonesia
\end{abstract}

\section{PENDAHULUAN}

Kuota telah diterima sebagai jalur cepat (fast track) untuk mewujudkan perimbangan gender dalam lembaga-lembaga pembuatan keputusan. Penggunaan strategi kuota telah mampu meningkatkan keterwakilan perempuan hingga 56,3\% di Rwanda (2008), 45\% di Swedia (2010), 44,5\% di Africa
Selatan (2009), 38,5 di Argentina (2008) (Women in National Parliament, http://www.ipu.org). Meski kontroversial, kini sudah lebih dari 100 negara mengadopsi strategi ini. Pada tahun 2003 para aktivis perempuan Indonesia berhasil memperjuangkan adanya aturan tentang kuota perempuan dalam 
Undang-undang no 12/2003 tentang Pemilu dan diperbaiki dalam UU 10/2008. Namun

pemberlakuan ketentuan kuota tersebut menemui banyak hambatan, diantaranya ialah keputusan Mahkamah Konstitusi untuk mengubah ketentuan calon terpilih bukan berdasar nomer urut sehingga praktis ketentuan kuota sulit dilaksanakan. Penelitian ini ingin menjelaskan mengapa pemberlakuan kebijakan kuota perempuan di Indonesia terhambat.

Tulisan ini menggunakan pendekatan kritis, metode analisa wacana kritis dan berperspektif feminis. Kajian politik feminist selalu didorong oleh keinginan untuk menyelesaikan persoalan-persoalan politik yang dihadapi perempuan (Krooka and Squires, 2006).

Penggunaan analisa wacana kritis (Critical Discourse of Analysis-CDA) disebabkan karena pendekatan ini dapat membantu menyingkap tabir-tabir terselubung yang ada dibalik realita sosial. Melalui CDA, peneliti berusaha mengungkap ideologi dan kepentingan politik yang berada di balik argumen-argumen yang menentang kuota perempuan. Ciri khas pendekatan kritis adalah curiga dan mempertanyakan secara kritis kondisi masyarakat saat ini.

Wacana dapat diartikan sebagai percakapan, teks, serangkaian kalimat yang saling berkaitan, bahasa lisan-komentar, hasil wawancara, ucapan dan pernyataan-pernyataan (Eriyanto, 2009: 2). Pidato, dialog, polemik, perdebatan, percakapan atau perbincangan juga dapat dikategorisasikan sebagai sebuah wacana. Karena itu penelitian ini akan menganalisa pernyatan-pernyataan dan komentar para aktor politik dan hasil wawancara penulis terhadap responden, terkait dengan kuota perempuan.

Dari berbagai varian analisa wacana, penulis memilih untuk menggunakan analisa CDA. Dengan menggunakan CDA penelitian ini ingin menunjukkan bagaimana gagasan perempuan, isu tentang ketimpangan gender disingkirkan dari konsep politik, demokrasi, perwakilan, sistem dan perundangundangan partai politik, pemilu dan penjaringan caleg didalam partai-partai politik, meski telah terdapat ketentuan kuota perempuan dalam Undang-undang Pemilu dan Undang-undang Partai Politik. Dengan disingkirkannya gagasan dan isu tentang perempuan maka kepentingan perempuan untuk memperoleh kuota 30\% keterwakilan di parlemen, kepentingan untuk memperoleh akses dalam pembuatan keputusan, dan kepentingan untuk mencapai kesetaraan dengan laki-laki juga ikut terpinggirkan.

Analisa Wacana Kritis (Critical Discourse of Analysis) menggunakan analisa kualitatif dan menggunakan penafsiran sebagai basis utama untuk memaknai temuan (Eriyanto, 2009: 49). Meski penafsiran dalam analisis wacana bersifat subyektif, tetapi dengan menghubungkannya dengan konteks, maka penafsiran tersebut mempunyai dasar argumentasi yang kuat (Eriyanto, 2009: 64). Analisa dilakukan dengan menafsirkan secara subyektif wacana (teks) yang diteliti. Penafsiran dilakukan dengan menghubungkan teks dengan konteksnya (siapa partisipan yang memproduksi wacana, seting sosial, historis, kepentingan, kekuasaan dan ideologi). Intinya, untuk memahami teks, perlu dipahami konteksnya.

Teks adalah semua bentuk bahasa baik yang tercetak (tulisan), maupun semua jenis ekspresi komunikasiucapan, gambar, musik, citra, suara dan lain-lain (Cook, Guy, 1994: 1). Konteks adalah semua situasi yang mempengaruhi teks, dapat dibagi dua yaitu partisipan wacana dan setting sosial. Partisipan wacana adalah siapa yang memproduksi wacana-apa jenis kelaminnya, berapa umurnya, apa pendidikannya, seperti apa kelas sosialnya dan apa agamanya. Seting sosial yaitu posisi dan aturan yang melingkupinya yang dapat diklasifikasikan dalam seting historis, seting kekuasaan dan seting ideology. Seting Historis yaitu dengan menghubungkan antara teks dengan setting sejarah, seperti bagaimana situasi sosial politik pada saat itu, mengapa wacana yang dikembangkan seperti itu, mengapa bahasa yang digunakan seperti itu. Setting Kekuasaan yaitu dengan menghubungkan antara teks dengan kekuatan politik (kontrol kelompok laki-laki terhadap perempuan). Ini dapat berupa kontrol fisik dan kontrol pikiran (hegemoni sebuah gagasan)-kontrol struktur wacana (kelompok laki-laki mempunyai kekuasaan besar untuk menentukan isu apa yang diangkat dalam RUU 
Parpol/RUU Pemilu DPR). Sedangkan seting Ideologi ialah bahwa teks dan percakapan akan mencerminkan ideologi subyeknya. Dari teks dapat dianalisa ideologi subyeknya (misal: liberal kapitalis, feminis dll). Ideologi dibangun oleh kelompok yang dominan (kelompok liberal-kapitalis) untuk mereproduksi dan melegitimasi dominasinya.

Telaah dilakukan pada tiga level analisa. Pertama, pada level normatif level normatif, dimana diperdebatkan dua gagasan keadilan: compensatory justice vs distributive justice. Kedua, pada level institusional, dimana kepentingan-kepentingan tersebut terjalin dalam suatu pola penataan, sebagaimana diungkap dalam rumusan ketentuan perperundang-undangan. Ketiga, pada level praktikal yang mengungkap kepentingan aktor dalam rekrutmen caleg.

Analisis secara simultan pada tiga level tersebut menunjukkaan bahwa pemberlakuan kuota perempuan di Indonesia terhambat karena kebijakan tersebut menghadapi konflik pada level normatif, level institusional dan level praktikal. Pada level normatif, pemberlakuan kuota berkonflik dengan hegemoni pemaknaan demokrasi dan perwakilan versi liberal. Pada level institusional pemberlakuan kuota berkonflik dengan sistem dan teknis pemilu (liberalmajoritarian) seperti yang tercantum dalam perundangundangan pemilu. Pada level praktikal pemberlakuan kuota menimbulkan konflik kepentingan antara kelompok yang diuntungkan dengan kelompok yang dirugikan oleh kebijakan kuota. Konflik ini mengakibatkan peminggiran perempuan yang dilakukan melalui mekanisme penjaringan caleg, pengaturan peserta Konggres/Munas dan konservasi gender politics dalam praktek partai politik.

Hegemoni norma liberal ditandai oleh ketidaksadaran para pelaku bahwa terdapat male biased dalam norma, pelembagaan dan praktek demokrasi liberal. Hegemoni tersebut telah merata baik dikalangan eksekutif, legeslatif, yudikatif maupun aktivis. Karena kendalanya bersifat hegemonik, maka upaya untuk menyusun peraturan perundangundangan tentang pemilu dan partai politik serta sistem rekruitmen caleg yang tidak menggunakan prinsip-prinsip demokrasi liberali sangat sulit tercapai. Akibatnya, perundang-undangan pemilu di Indonesia yang dibangun diatas prinsip-prinsip liberal majoritarian justru menfasilitasi dominasi laki-laki dalam politik. Meski dalam pemilu 2009 keterwakilan perempuan di DPR naik hingga mencapai 18\% namun dalam 10 kali pemilu yang diselenggarakan sejak kemerdekaan Indonesia, laki-laki tetap mendominasi lebih dari $80 \%$ kursi DPR.

Konflik pada ketiga level tersebut menghadirkan dilema bagi perempuan. Di satu sisi model liberal telah menjadi regime demokrasi di Indonesia sehingga jika perempuan ingin berpolitik mereka harus mengikuti aturan main liberal, namun di sisi lain aturan main liberal ini menghambat pemberlakuan kuota perempuan dan melanggengkan dominasi lakilaki dalam arena politik Indonesia. Konflik pada ketiga level tersebut dapat dijelaskan sebagai berikut.

\section{PEMBAHASAN}

\section{KONFLIK PADA LEVEL NORMATIF}

Pada level normatif, pemberlakuan kuota berkonflik dengan hegemoni pemaknaan demokrasi dan perwakilan versi liberal. Reformasi demokrasi di Indonesia tidak dapat dipisahkan dari perkembangan rejim demokrasi dunia. Pasca kejatuhan Uni Soviet, Amerika Serikat semakin gencar dalam mempromosikan ideologi demokrasi liberal kapitalis. Demokrasi liberal menjadi seperangkat nilai universal yang siap diekspor ke seluruh penjuru dunia, terutama ke negara-negara yang sedang membangun sistem demokrasinya, termasuk Indonesia. Akibatnya, modelmodel demokrasi lainnya seperti demokrasi sosial (social welfare democracy) yang lebih menekankan pada kesejahteraan rakyat menjadi tidak terdengar. ${ }^{1}$ Demokrasi liberal menjadi model hegemonik yang dianggap sebagai model terbaik.

Untuk mendukung promosi demokrasi tersebut Amerika Serikat membentuk The National Endowment for Democracy (NED) yang mendanai lebih dari 1,000 proyek bagi NGOs diluar negeri yang bergerak dibidang demokrasi di lebih dari 90 negara. Sebagian besar dana NED mengalir ke empat lembaga prpmotor 
demokrasi besar yaitu The Center for International Private Enterprise (CIPE), The American Center for International Labor Solidarity (ACILS), The International Republican Institute (IRI), dan The National Democratic Institute for International Affair (NDI) yang berperan besar dalam pendanaan proyek-proyek demokrasi di Indonesia.

Meski demikian adanya konflik normatif antara kebijakan kuota dengan norma-norma demokrasi liberal ini tidak kasat mata sehingga para aktivispun banyak yang tidak menyadarinya. Banyak diantara aktivis yang berperan ganda, sebagai pendukung kuota dan juga sebagai pengusung norma demokrasi liberal. Beberapa jaringan advokasi antar negara (TAN's) seperti International IDEA, lembaga penghubung donor seperti Partnership for Governance, organisasi non pemerintah seperti CETRO dan pemerintah Republik Indonesia sendiri juga berperan ganda sebagai pendukung kuota sekaligus pengusung demokrasi liberal, tanpa menyadari adanya kontradiksi normatif didalamnya. Ambivalensi ini sulit terelakkan mengingat sebagian besar dana advokasi kuota maupun demokrasi berasal dari sumber yang sama yaitu donor asing.

Pasca reformasi prinsip-prinsip demokrasi liberal yang menekankan equal opportunity dan individual right berhasil menjadi norma demokrasi yang diyakini kebenarannya dan mempunyai posisi hegemon dikalangan legeslatif (pembuat undang-undang/DPRpimpinan partai), yudikatif (Mahkamah Konstitusi), dan aktivis demokrasi Indonesia. Hegemoni norma liberal ini membuat gagasan kuota perempuan yang menekankan prinsip equality of result dan collective right sulit diterima maupun dilaksanakan karena dianggap bertentangan dengan prinsip-prinsip demokrasi. ${ }^{2}$ Menurut liberal, kesetaraan gender diupayakan dicapai melalui perbaikan kondisi sosial ekonomi

(pemberdayaan) perempuan, bukan melalui intervensi pemerintah.

Konsep-konsep utama demokrasi liberal seperti individual, equal opportunity dan one person one vote one value (OPOVOV) yang digunakan sebagai bahan baku bagi pembangunan teori-teori demokrasi dan pemilihan umum yang mereka klaim dapat menjelaskan "realita" dunia, terbukti bias gender sehingga tidak dapat dikatakan obyektif. Konsepkonsep ini bias gender karena pemahamannya tentang manusia, tentang sifat manusia, hanya didasarkan pada asumsi sifat manusia yang maskulin (Pirages and Sylvester, 1989). Dasar berfikir ini menjadi tidak representatif, karena ternyata isi bumi adalah manusia laki-laki dan perempuan. Bukan hanya laki-laki saja.

Penggunaan konsep individual dalam demokrasi liberal didasarkan pada pengalaman laki-laki dalam bermasyarakat. Yang dimaksud dengan individu dalam konsep demokrasi liberal adalah orang yang mempunyai karakter autonomy (kemandirian), rationality (penalaran), mempunyai kemampuan untuk memilih (ability to make choices ) dan membuat kontrak/ perjanjian dengan pihak lain. Karakter-karakter tersebut adalah karakter yang selalu melekat pada maskulinitas. Sebaliknya, sebagian besar perempuan tidak memenuhi criteria sebagai individu. Karena itu pengabstrakan laki-laki dan perempuan dalam konsep individu menjadi menyesatkan karena tidak sesuai dengan realita masyarakat.

Penggunaan prinsip OPOVOV yang meminta pemilih untuk memilih satu nama calon/partai saja dalam sebuah pemilu cenderung akan menguntungkan laki-laki. Dalam masyarakat yang dipengaruhi oleh tradisi patriarkhi, satu suara tersebut cenderung diberikan pada calon yang berjenis kelamin laki-laki. Seandainya sistem pemilu bersifat netral, tidak bias gender, mestinya penggunaan sistem tersebut tidak akan mengakibatkan tingginya kesenjangan gender di parlemen secara terus menerus seperti yang terjadi selama ini. Baru pada tahun 1990an muncul kesadaran bahwa sitem pemilu tidak bersifat 'netral' sehingga kalangan feminis mulai mengupayakan reformasi sistem pemilu yang lebih bersahabat bagi perempuan.

Penggunaan norma equal opportunityy dan impartiality hanya akan menguntungkan kelompok dominan (laki-laki). Jika semua individu diberi hak yang sama (equal right), maka kepentingan dari kelompok dominanlah yang akan berlaku karena mereka akan 


\section{Ilustrasi 1}

Sistem Pemilu Liberal (Indonesia Pasca Reformasi)
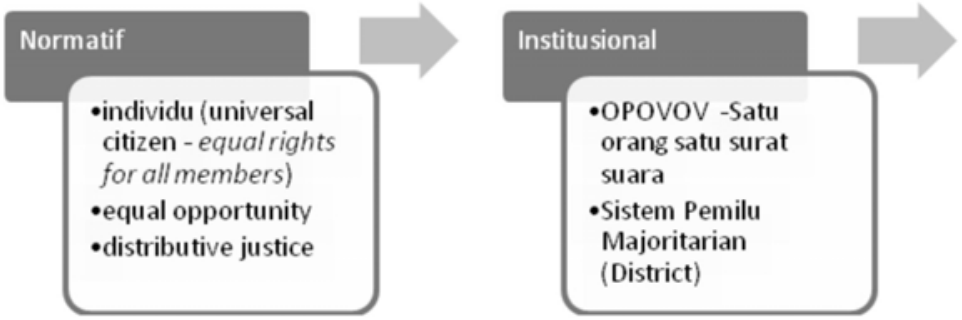

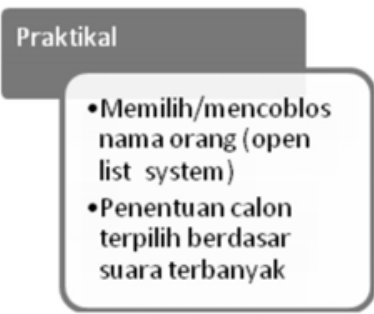

menyatakan bahwa pengalaman dan cara pandang mereka tentang realitas social sebagai suatu hal yang obyektif dan tidak memihak (Young, 1989: 259). Artinya, norma kelompok dominan (laki-laki) lah yang menjadi standar. Atas nama obyektifitas dan ketidakberpihakan (impartiality) maka kelompokkelompok minoritas, termasuk perempuan, menjadi terpinggirkan dalam kehidupan politik. Atas nama universalism maka norma-norma asli yang semula dipunyai oleh kelompok-kelompok minoritas, termasuk perempuan, menjadi terdegradasi. Sebaliknya, norma laki-laki menjadi standar.

Obsesi akan stabilitas menjadikan sistem pemilu cenderung konservatif (mendukung status quo) dan meminggirkan perempuan. Baik dari sisi teori maupun praktek, sistem pemilu yang dipraktekkan dinegara-negara demokrasi liberal seperti Amerika Serikat dan Eropa Barat cenderung dianggap sebagai sebuah standar (norm). Aktor-aktor politik yang diuntungkan dengan pemikiran dan praktek sistem pemilu tersebut cenderung mengkonservasi sistem sehingga pemikiran tentang reformasi sistem pemilu sulit untuk diterima.

Penggunaan prinsip OPOVOV misalnya, cenderung mengunci munculnya alternatif/inovasi sistem pemilu dengan basis kelompok (group right) yang memungkinkan penggunaan reserved seats, pemisahan penghitungan suara bagi caleg perempuan dan laki-laki, penggunaan dual ballot ( satu surat suara untuk memilih caleg perempuan, dan satu surat suara untuk memilih caleg laki-laki) atau pemilihan caleg secara kolektif yang mengharuskan pemilih memilih satu calon perempuan dan satu calon laki-laki. Terkuncinya inovasi sistem pemilu memaksa perempuan untuk bertarung dalam kerangka sistem pemilu District, Proporsional Representative (PR) atau campuran diantara keduanya, yang cenderung male bias tersebut.

\section{KONFLIK PADA LEVEL PELEMBAGAAN}

Pada level institusional pemberlakuan kuota berkonflik dengan sistem dan teknis pemilu (liberalmajoritarian) seperti yang tercantum dalam perundangundangan pemilu. Hegemoni norma liberal dalam demokrasi dan perwakilan di Indonesia tersebut mendorong terbentuknya institusi (UU Parpol dan UU Pemilu) dan praktek penentuan calon terpilih yang tidak sesuai dengan kebutuhan kuota, sehingga penghambat pemberlakuan kebijakan kuota, terlihat dalam ilustrasi 1.

Pengalaman di berbagai negara seperti Rwanda, Inggris, Canada, New Zealand, India dan lain-lain menunjukkan bahwa keberhasilan peningkatan keterwakilan perempuan selalu didahului dengan electoral engineering (perekayasaan sistem pemilu) atau lebih tepatnya reformasi/inovasi sistem dan teknis pemilu yang memberikan peluang lebih besar bagi perempuan untuk terpilih. Di Indonesia, electoral engineering semacam ini belum pernah dilakukan. Rendahnya keterwakilan perempuan tidak dianggap sebagai problem yang perlu diatasi melalui reformasi sistem pemilu, selain penggunaan kuota. Aktor-aktor politik yang diuntungkan oleh sistem ini cenderung mengkonservasi sistem pemilu sehingga tidak terjadi reformasi sistem pemilu yang menguntungkan perempuan. Resistensi pemerintah dan politisi terhadap usulan kuota perempuan pada awal reformasi 
Tabel 1

Varian Demokrasi berdasar Prosedur Kerja

\begin{tabular}{|c|c|c|c|}
\hline & MODEL AGGREGATI $F$ & MODEL DELIBERATIF & MODEL ANTI DOMINASI \\
\hline Konseptualisasi & $\begin{array}{l}\text { Membayangkan institusi } \\
\text { demokrasi sebagai sarana } \\
\text { untuk mengetahui dan } \\
\text { mengumpulkan preferensi } \\
\text { warga Negara. }\end{array}$ & $\begin{array}{l}\text { Membayangkan demokrasi } \\
\text { sebagai sarana untuk } \\
\text { mendiskusikan persoalan } \\
\text { yang dihadapi masyarakat } \\
\text { dan saling berargumen } \\
\text { untuk mencari solusi. }\end{array}$ & $\begin{array}{l}\text { Membayangkan demokrasi } \\
\text { sebagai sarana untuk } \\
\text { mencegah terjadinya } \\
\text { kesewenang-wenangan } \\
\text { dalam penggunaan } \\
\text { kekuasaan. }\end{array}$ \\
\hline Prosedur Kerja & $\begin{array}{l}\text { Model ini menjadikan } \\
\text { "voting /pemilihan umum" } \\
\text { sebagai alat politik } \\
\text { terpenting dalam demokrasi }\end{array}$ & $\begin{array}{l}\text { Ddemokrasi harus } \\
\text { memberikan akses bagi } \\
\text { warganegaranya untuk } \\
\text { mengekspresikan sikap dan } \\
\text { gagasan. }\end{array}$ & $\begin{array}{l}\text { Kekuasaan (power) tidak } \\
\text { boleh dimonopoli oleh } \\
\text { sebuah lembaga/orang. }\end{array}$ \\
\hline $\begin{array}{l}\text { Dampak terhadap } \\
\text { Perempuan dan } \\
\text { Minoritas }\end{array}$ & $\begin{array}{l}\text { Voting cenderung } \\
\text { menguntungkan Mayoritas } \\
\text { (Laki-laki-Kel. Dominan) }\end{array}$ & $\begin{array}{l}\text { Perempuan sulit } \\
\text { memperoleh akses }\end{array}$ & $?$ \\
\hline
\end{tabular}

Tabel 2

Varian Demokrasi Berdasar Sikap terhadap Minoritas

\begin{tabular}{|c|c|c|c|c|c|}
\hline & $\begin{array}{l}\text { INDIVIDUAL } \\
\text { LIBERAL } \\
\text { DEMOCRACY }\end{array}$ & $\begin{array}{l}\text { REPUBLICAN } \\
\text { LIBERAL } \\
\text { DEMOCRACY }\end{array}$ & $\begin{array}{l}\text { MULTICULTURAL } \\
\text { DEMOCRACY }\end{array}$ & $\begin{array}{l}\text { CONSOCIATIONAL } \\
\text { DEMOCRACY }\end{array}$ & $\begin{array}{l}\text { ETHNIC } \\
\text { DEMOCRACY }\end{array}$ \\
\hline Sifat Negara & $\begin{array}{l}\text { Kumpulan dari } \\
\text { Warga Negara }\end{array}$ & $\begin{array}{l}\text { Civic } \\
\text { nationstate }\end{array}$ & $\begin{array}{l}\text { Negara } \\
\text { multicultural }\end{array}$ & $\begin{array}{l}\text { Negara Multi } \\
\text { Nasional } \\
\text { Mempunyai dua } \\
\text { atau lebih dua } \\
\text { budaya, bahasa, } \\
\text { bangsa, yang } \\
\text { diakui secara } \\
\text { formal dan } \\
\text { menjadi basis } \\
\text { manajemen politik. }\end{array}$ & $\begin{array}{l}\text { Ethnic nation- } \\
\text { state. } \\
\text { Ethnic utama } \\
\text { mengontrol } \\
\text { Negara dan } \\
\text { memperoleh status } \\
\text { istimewa, etnik } \\
\text { minorotas menjadi } \\
\text { warga Negara } \\
\text { kelas dua. }\end{array}$ \\
\hline Contoh & $\begin{array}{l}\text { USA } \\
\text { Indonesia? }\end{array}$ & Perancis & $\begin{array}{l}\text { USA? } \\
\text { Indonesia? }\end{array}$ & Belgia & Israel \\
\hline $\begin{array}{l}\text { Pengakuan } \\
\text { terhadap Hak } \\
\text { Kolektif }\end{array}$ & Tidak ada & Tidak ada & $\begin{array}{l}\text { Secara factual } \\
\text { diakui, tetapi } \\
\text { aturan hukum } \\
\text { tidak didasarkan } \\
\text { pada Hak } \\
\text { Kolektif }\end{array}$ & $\begin{array}{l}\text { Diakui dalam } \\
\text { Undang-undang }\end{array}$ & $\begin{array}{l}\text { Diakui dalam } \\
\text { Undang-undang }\end{array}$ \\
\hline $\begin{array}{l}\text { Sikap } \\
\text { terhadap } \\
\text { Perempuan } \\
\text { dan } \\
\text { Kelompok } \\
\text { Minoritas }\end{array}$ & $\begin{array}{l}\text { Rendahnya } \\
\text { keterwakilan } \\
\text { perempuan } \\
\text { adalah urusan } \\
\text { perempuan } \\
\text { sbg individu }\end{array}$ & $\begin{array}{l}\text { Kepentingan } \\
\text { perempuan } \\
\text { harus } \\
\text { tunduk/dibawa } \\
\text { h kepentingan } \\
\text { nasional }\end{array}$ & $\begin{array}{l}\text { Ada upaya untuk } \\
\text { mengakomodasi } \\
\text { fakta akan } \\
\text { adanya } \\
\text { keberagaman } \\
\text { etnik, bahasa, } \\
\text { agama. Namun } \\
\text { tidak/belum } \\
\text { tentu ada upaya } \\
\text { untuk menjamin } \\
\text { keterwakilan } \\
\text { gender. }\end{array}$ & $\begin{array}{l}\text { Bahasa, etnik, } \\
\text { agama diakui } \\
\text { sebagai identitas } \\
\text { politik tetapi } \\
\text { gender belum } \\
\text { tentu diakui } \\
\text { sebagai identitas } \\
\text { politik }\end{array}$ & $\begin{array}{l}\text { etnik, agama } \\
\text { diakui sebagai } \\
\text { identitas politik } \\
\text { tetapi gender } \\
\text { belum tentu diakui } \\
\text { sebagai identitas } \\
\text { politik }\end{array}$ \\
\hline
\end{tabular}

Sumber: Smooha, Sammy. 2001. The Model of Ethnic Democracy. ECMI Working Paper, 13 October

dan ketiadaan sanksi bagi partai yang tidak memenuhi ketentuan kuota menunjukkan sikap pembuat undangundang yang cenderung mengkonservasi sistem pemilu yang telah ada karena sistem tersebut menguntungkan mereka (laki-laki).

Pemikiran tentang reformasi sistem pemilu yang pro perempuan sulit untuk diterima. Pembahasan tentang perlunya inovasi sistem dan teknis pemilu (electoral 
engineering) yang bersifat emansipatoris dan lebih sesuai dengan logika kuota ini jarang dibahas karena para ahli politikpun cenderung berpendapat bahwa pemilu model liberal (distrik/majoritarian, perwakilan berimbang/Proportional Representative) adalah standar yang sulit diubah. Para ahli politik juga cenderung memaknai demokrasi sebagai sarana untuk mengetahui dan mengumpulkan preferensi warga Negara melalui "voting / pemilihan umum" (Model Demokrasi Agregarif). ${ }^{3}$

Sebagai dampak dari kegencaran Amerika Serikat dalam mempromosikan demokrasi liberal, maka paska Perang Dingin pewacanaan demokrasi dihegemoni oleh model demokrasi liberal. Terdapat kesan bahwa demokrasi liberal adalah 'bentuk ideal dari organisasi politik' sehingga bentuk-bentuk demokrasi lainnya cenderung tidak memperoleh tempat. Meski demikian sesungguhnya terdapat berbagai varian demokrasi.

Dilihat dari proses bekerjanya, demokrasi dapat dibedakan dalam tiga model, yaitu Model Aggregative, Model Deliberative dan Model Anti Dominasi. Dilihat dari sikapnya terhadap kelompok-kelompok minoritas, demokrasi dapat dibedakan dalam demokrasi liberal individual, demokrasi liberal republican, demokrasi multi kultural, demokrasi konsociational dan demokrasi etnik. Dilihat dari basis pemberian hak politik, demokrasi dapat memberikan hak politik pada individu (individual liberal democracy, republican liberal democracy), dan demokrasi yang memberikan hak politik secara kolektif (consociational democracy dan ethnic democracy). Sedangkan multicultural democracy berada diantara demokrasi liberal dan demokrasi konsociational. Jika dilihat dari aspek pengelolaan ekonomi demokrasi demokrasi dapat dibedakan dalam demokrasi liberalism kapitalis dan demokrasi social (social democracy). Demokrasi liberal kapitalis memberikan peran minimal pada Negara, sebaliknya demokrasi social memberikan peran yang cukup besar pada Negara dalam pengelolaan ekonomi dan sosial. Uraian singkat dari masing-masing varian demokrasi tersebut dapat dilihat dalam tabel-tabel terlampir.

Pasca reformasi politik 1998, karakter liberal
Tabel 3

\section{Varian Demokrasi berdasar Pengelolaan Negara} terhadap Ekonomi

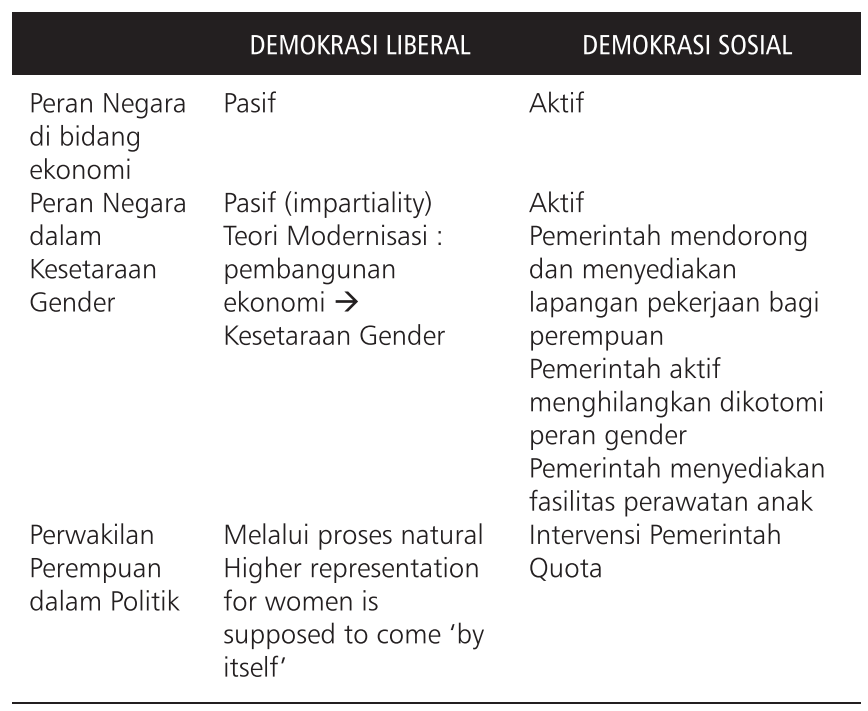

individual dalam demokrasi Indonesia tampak semakin kuat. Hal ini tercermin , misalnya dalam ketentuan tentang Pemilihan Umum yang meminta pemilih untuk memberikan suaranya langsung pada calon (individu), penggunaan prinsip universal citizenship, penggunaan prinsip OPOVOV dalam pemilu dan digunakannya sistem majoritarian (suara terbanyak) untuk menentukan calon terpilih. Intinya, pemilu menjadi arena kompetisi antar individu (caleg).

Pasca reformasi meski secara formal sistem pemilu Indonesia bernama proporsional namun secara esensial mekanisme penentuan calon terpilih didasarkan pada system majoritarian (suara terbanyak). Sistem pemilu ini menyulitkan perempuan. Pertama, dalam sistem majoritarian (suara terbanyak), dimana pemilih diminta memilih caleg dalam surat suara, gerakan perempuan akan kesulitan untuk menuntut pemenuhan isu gender pada setiap caleg yang jumlahnya amat sangat banyak (dapat mencapai puluhan ribu orang). Kedua, dengan sistem majoritarian, pemilu cenderung menjadi urusan individual. Dengan sistem pemilu yang berorientasi pada individu calon, tautan antara pemilih dengan calon lebih banyak bersifat klientelistik dan kharismatik. Artinya pemilih memilih caleh lebih karena pertimbangan keuntungan material yang 
diperoleh dari caleg atau karena kharisma caleg (Kitschelt, 2000).

\section{Tabel 4}

\section{Variabel Sistem Pemilu yang Akomodatif terhadap} Perempuan

\begin{tabular}{llll} 
& $\begin{array}{l}\text { AKOMODATIF } \\
\text { TERHADAP } \\
\text { PEREMPUAN }\end{array}$ & $\begin{array}{l}\text { KONDISI } \\
\text { DI INDONESIA } \\
\text { (2009) }\end{array}$ \\
\hline 1 Formula & $\begin{array}{l}\text { Perwakilan } \\
\text { penentuan calon } \\
\text { terpilih (electoral } \\
\text { formula) }\end{array}$ & $\begin{array}{l}\text { Suara } \\
\text { (Proporsional) }\end{array}$ & $\begin{array}{l}\text { terbanyak } \\
\text { (majoritarian) }\end{array}$ \\
$2 \begin{array}{l}\text { Luasan daerah } \\
\text { pemilihan (district } \\
\text { magnitude) }\end{array}$ & Luas & DPR : 3-10 \\
DPRD : 3-12 \\
$\begin{array}{l}\text { Struktur surat suara } \\
\text { (ballot structures) } \\
\text { Jenis daftar calon } \\
\text { (open/closed lists) }\end{array}$ & Memilih & Partai \\
Tertutup & $\begin{array}{l}\text { Calon } \\
\text { Terbuka }\end{array}$ \\
\hline
\end{tabular}

Menurut Kitschelt terdapat tiga pola hubungan caleg dengan pemilih dalam sistem politik demokratik, yaitu pola karismatik, pola klientelistik dan pola programatik. Pola kharismatik terjadi jika pemilih memberikan suaranya berdasar kharisma caleg. Pola klientelistik, terjadi jika pemilih memberikan suaranya berdasarkan pertimbangan keuntungan (material) yang diperoleh secara langsung kepadanya. Sedangkan pola programmatik terjadi jika pemilih memperikan suaranya karena program partai yang ditawarkan memang menarik (Kitschelt, 2000).

Penelitian ini menunjukkan bahwa sistem pemilu Indonesia selama ini yang mengarah pada sistem majoritarian (suara terbanyak) membuat kebijakan kuota perempuan sulit dilaksanakan. Keputusan MK NOMOR 22-24/PUU-VI/2008 yang menentuan calon terpilih harus didasarkan pada suara terbanyak secara berurutan menjadikan klausul tentang kuota perempuan kehilangan "roh" nya karena perjuangan perempuan untuk "memaksa" partai-partai politik menempatkan perempuan di nomer urut kecil menjadi kehilangan dasar pijakannyai seperti terlihat dalam ilustrasi berikut.

\section{Ilustrasi 2}

\section{Ketidaksinkronan antara Sistem Pemilu Indonesia dengan Ketentuan Kuota Perempuan}

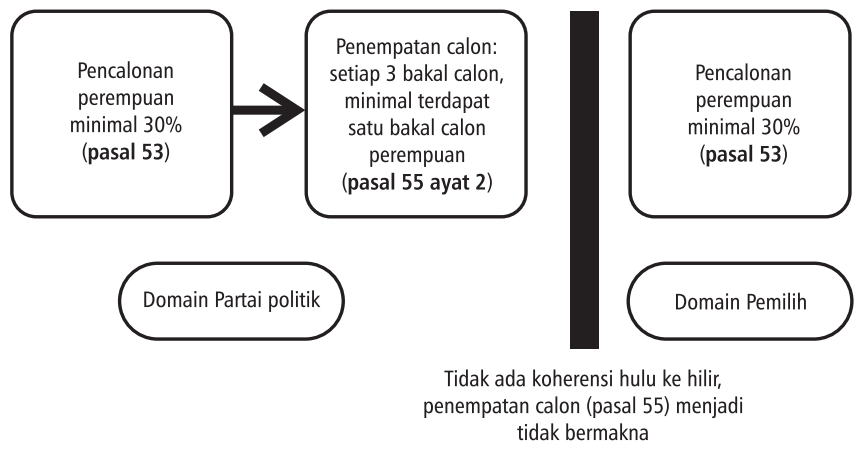

Sumber: Soetjipto, Ani. 2009. Dampak Diterapkannya Aturan Suara Terbanyak terhadap Keterwakilan Perempuan dan Gerakan Perempuan. Jakarta: Women Research Institute

\section{KONFLIK PADA LEVEL PRAKTIKAL}

Pada level praktikal pemberlakuan kuota menimbulkan konflik kepentingan antara kelompok yang diuntungkan dengan kelompok yang dirugikan oleh kebijakan kuota. Konflik ini mengakibatkan peminggiran perempuan yang dilakukan melalui mekanisme penjaringan caleg, pengaturan peserta Konggres/Munas dan konservasi gender politics dalam praktek partai politik.

Meski telah ada ketentuan kuota namun praktik di dalam partai politik masih meminggirkan perempuan. Peminggiran dilakukan dengan mempraktekkan gender politics, pembuatan aturan tentang peserta Konggres/ Munas partai yang mengkaitkan legalitas peserta dengan jabatan struktural partai di setiap level (DPD/ DPW, DPC) sehingga sulit ditembus oleh perempuan, dan pembuatan aturan penjaringan caleg dengan menggunakan prinsip meritokrasi-scoring.

Pemberlakuan kuota secara sungguh-sungguh jelas akan menguntungkan sekelompok orang (caleg perempuan) dan merugikan sekelompok yang lain (caleg laki-laki) sehingga menimbulkan konflik kepentingan. Konflik kepentingan dan perebutan kekuasaan ini membuat pihak yang dirugikan akan berupaya menghambat pemberlakuan kuota dan meminggirkan posisi perempuan dengan berbagai cara.

Gender politics dilakukan dengan mengelompokkan 
perempuan dalam organisasi sayap perempuan yang aktifitasnya cenderung mengikuti ideology gender yang telah tertanam kuat di masyarakat yaitu urusan keluarga, anak, kesehatan dan kesejahteraan sosial. Proses domestikasi ini menyebabkan perempuan Indonesia sulit untuk diorganisir agar mampu mendekonstruksi institusi partai yang mendiskriminasikan mereka. Tidak mengherankan jika sedikit sekali perempuan yang dapat menempati kepengurusan strategis partai (Cario, Argentina).

Peminggiran perempuan juga dilakukan dengan pembuatan aturan tentang peserta Konggres/Munas partai yang sulit ditembus oleh perempuan sehingga arena tersebut selalu didominasi laki-laki. Pengaturan Konggres yang mengkaitkan legalitas peserta dengan jabatan struktural partai di setiap level (DPD/DPW, DPC) praktis telah meminggirkan perempuan dalam proses-proses pembuatan keputusan partai karena sulit sekali bagi perempuan untuk dapat menduduki posisi puncak di DPD/DPW dan DPC.

Peminggiran perempuan berikutnya dilakukan dalam proses penjaringan caleg partai. Pada proses penjaringan caleg peminggiran perempuan terjadi ketika partai-partai menggunakan prinsip meritokrasiscoring yang memperlakukan bakal caleg laki-laki maupun perempuan secara sama. Jika menggunakan affirmative action semestinya caleg perempuan diperlakukan secara berbeda dengan caleg laki-laki. Meski partai mengaku telah melakukan affirmative action, namun norma yang digunakan dalam proses penjaringan caleg adalah equality of opportunity, netralitas Negara (panitia seleksi) dan individual right yang bertentangan dengan logika kuota. Baik partai maupun masyarakat berpandangan bahwa pemilu yang demokratis adalah pemilu yang menempatkan pemilih dan peserta pemilu secara setara.

Mekanisme penjaringan bakal caleg di berbagai partai tersebut maka dapat diklasifikasikan dalam tiga kelompok yaitu dengan menggunakan sistem skoring (Golkar, PDIP, PAN, PKB), dengan perolehan suara dalam Pemilu Raya (PKS) dan dengan Musyawarah (PPP).

Sistem Pemilu Raya dan sistem skoring menghasilkan angka-angka yang bersifat kuantitatif yang akan digunakan sebagai dasar pengurutan calon, baik laki-laki maupun perempuan. Artinya, denga angka yang kongkrit seperti ini, tindakan affirmative action terhadap calon perempuan akan sulit dilakukan, karena dapat dianggap sebagai manipulasi skor atau penghianatan terhadap mekanisme demokrasi. Pada beberapa partai memberikan sistem quota pada penjaringan bakal calon pada level pertama. Level-level seteruanya harus diikuti dengan sistem skoring. Ada pula partai yang menambahkan skor khusus untuk perempuan, tetapi penambahan tersebut tidak significant. PAN menambahkan skor 5 (lima) bagi perempuan, dengan total skor maksimal sekitar 100 .

Scoring system kerap dianggap sebagai sistem yang terbaik. Padahal ketika sistem scoring mencampurkan dalam satu list antara bakal caleg laki-laki dan perempuan maka akan menggugurkan sistem kuota perempuan. Perempuan bakal caleg sendiri pada umumnya tidak menyadari bahwa dengan system scoring berarti laki-laki maupun perempuan diperlakukan secara sama. Jika menggunakan prinsip quota, semestinya scoring harus dipisahkan dalam dua kelompok, laki-laki dan perempuan. Kuota adalah hak perempuan secara kolektif. Skoring didasarkan pada prinsip equal opportunity, sedangkan kuota didasarkan pada equality of result. Penggunaan scoring dapat dimaknai sebagai strategi untuk melumpuhkan system kuota.

Jika penentuan nomer urut dilakukan secara musyawarah maka akan menghasilkan penilaian yang kualitatif. Dengan sistem ini sebenarnya lebih memungkinkan adanya affirmative action untuk bakal caleg perempuan. Tetapi jika peserta musyawarah sebagian besar adalah laki-laki, maka suara bagi bakal caleg perempuan juga akan sangat kecil. Masalah utamanya ialah akses perempuan untuk terlibat sebagai peserta musyawarah (tim seleksi) sangat kecil sehingga peluang untuk mempengaruhi keputusan juga sangat kecil. Untuk itu kehadiran fisik perempuan dalam tim musyawarah sangat penting. Dalam partai-partai yang bernuansa Islam, otoritas kyai atau tokoh agama dalam proses musyawarah juga sangat tinggi. Jika para tokoh 
Tabel 5

Proses Penjaringan Caleg PAN-Golkar-PDIP Pemilu 2004

\begin{tabular}{|c|c|c|}
\hline PAN & GOLKAR & PDIP \\
\hline $\begin{array}{l}\text { - Platform partai menyebut } \\
\text { secara jelas tentang } \\
\text { perempuan dan politik yang } \\
\text {, di bahas secara khusus } \\
\text { - Struktur partai : dibentuk } \\
\text { Perempuan PAN (PUAN) } \\
\text { sebagai organisasi otonom } \\
\text { perempuan }\end{array}$ & $\begin{array}{l}\text { - Tahun } 2002 \text { Dibentuk KPPG yaitu } \\
\text { departemen perempuan } \\
\text { - Kelembagaan sayap melalui KPPG dan } \\
\text { AMPG } \\
\text { - Hasil Rapim VI tahun } 2003 \text { menetapkan } \\
\text { komitmen Golkar ttg 30\% kuota } \\
\text { perempuan dalam penjaringan tingkat } \\
\text { pertama }\end{array}$ & $\begin{array}{l}\text { - Sebelum th } 2002 \text { : PDIP } \\
\text { sudah punya kebijakan } \\
\text { affirmatif } 20 \% \text { pengurus } \\
\text { cabang perempuan }\end{array}$ \\
\hline $\begin{array}{l}\text { - Kebijakan partai diputuskan } \\
\text { dalam forum kongres dan } \\
\text { rakernas, dimana masalah } \\
\text { perempuan dibahas dalam } \\
\text { komisi sendiri. Menunjukkan } \\
\text { perempuan ditangani secara } \\
\text { signifikan } \\
\text { - Kebijakan affirmatif untuk } \\
\text { nominasi perempuan: } \\
\text { - Keputusan ketua umum dan } \\
\text { sekjen tentang skoring. } \\
\text { Calon perempuan } \\
\text { mendapat nilai tambah } 5 \\
\text { point dari skor total yang } \\
\text { diperoleh nilai tertinggi } 100\end{array}$ & $\begin{array}{l}\text { Syarat Caleg } \\
\text { - Anggota yang berjuang aktif } 5 \text { tahun terus } \\
\text { menerus } \\
\text { - Ikut pelatihan dan pendidikan kader } \\
\text { - Melalui penugasan fungsionaris } \\
\text { - Memiliki PD2LT } \\
\text { - Mempunyai pengaruh/dukungan luas } \\
\text { - Kualitas pendidikan? } \\
\text { O DPRRI:SI/akademi/lemhanas/se } \\
\text { sdiknas. } \\
\text { O DPRD/Provinsi:minimal SLTA atau } \\
\text { berpengetahuan sederajat } \\
\text { Tatacara pemilihan Caleg } \\
\text { - DPP Mempersiapkan bakal caleg } 4 \text { kali } \\
\text { dari jumlah anggota DPR } 22000 \text { disusun } \\
\text { dalam Dpdicalonkan sehingga } \\
\text { masingmasing provinsi dan bagian prov. } \\
\text { - Punya bakal calon } 4 x \text { jumlah anggota DPR } \\
\text { - Daftar nama -nama dikirim ke DPP Partai } \\
\text { kepada DPD Provinsi } \\
\text { - Untuk DPRD Prov dan kab }\end{array}$ & $\begin{array}{l}\text { - Rekruitmen dan nominasi } \\
\text { caleg dimulai dari ranting } \\
\text { o PAC }=50 \% \\
\text { ○ DPC }=45 \% \\
\text { o DPD }=5 \% \\
\text { - Tidak akan mengambil } \\
\text { caleg dari luar } \\
\text { Caleg DPR } \\
\text { - } \quad 40 \% \text { caleg usulan pusat } \\
\text { - } \quad 30 \% \text { usullan DPD } \\
\text { - } \quad 30 \% \text { usulan DPC. }\end{array}$ \\
\hline $\begin{array}{l}\text { Skoring : } \\
\text { - } \text { Alokasi } 20 \% \text { untuk caleg } \\
\text { dari luar partai } \\
\text { - Nilai - (minus) } 20 \text { dibagi } \\
\text { caleg yang telah menjadi } \\
\text { legislatif dan eksekutif. } \\
\text { - } \text { Rumusan penetapan caleg } \\
\text { terpilih } 1 / 2 N+1 \text { bagi yang } \\
\text { tak memenuhi BPP langsung } \\
\text { jadi calon terpilih }\end{array}$ & $\begin{array}{l}\text { Skoring: } \\
\text { - } \quad \text { Kemampuan/kapabilitas (intelektualitas } \\
\text { dan pengalaman) } \\
\text { - } \quad \text { Dukungan konstituen dan ketokohan } \\
\text { - } \quad \text { Kepentingan partai (PD2LTprestasi, } \\
\quad \text { dedikasi, disiplin, loyalitas tidak tercela) }\end{array}$ & \\
\hline
\end{tabular}

Sumber: Diolah dari CETRO

agama tersebut memberikan dukungannya pada bakal caleg laki-laki, maka bakal caleg perempuan juga akan terpinggir.

\section{KESIMPULAN}

Riset ini telah menawarkan pengggunaan tiga level analisa yaitu level praktikal (kepentingan aktor dalam rekrutmen caleg) yang bersifat kasat mata, level institusional (perundang-undangan Pemilu dan Partai Politik) yang agak abstrak dan level normatif (compensa- tory justice vs distributive justice) yang bersifat abstrak secara simultan untuk mengungkap hambatan pemberlakuan kuota di Indonesia.

Penggunaan tiga level analisa secara simultan untuk mengungkap hambatan pemberlakuan kuota di Indonesia tersebut menjadikan disertasi ini berbeda dengan desertasi Wahidah br Siregar yang mengungkap tidak tercapainya kuota 30\% keterwakilan perempuan dari level institusional (sistem pemilu tertutup vs sistem pemilu suara terbanyak /majoritarian). 
Tabel 6

Proses Penjaringan Caleg PBB-PPP-PKB-PKS Pemilu 2004

\begin{tabular}{|c|c|c|c|}
\hline PBB & PPP & PKB & PKS \\
\hline $\begin{array}{l}\text { - Menempatkan } \\
\text { Perempuan pada } \\
\text { urutan pertama di } \\
\text { wilayah yang } \\
\text { memiliki } 4 \text { atau } \\
\text { lebih daerah } \\
\text { pemilihan } \\
\text { - Salah satu daerah } \\
\text { pemilihan itu, } \\
\text { calon perempuan } \\
\text { ditempatkan pada } \\
\text { urutan pertama }\end{array}$ & $\begin{array}{l}\text { - Partai ini karena kultur } \\
\text { dan tradisi tidak secara } \\
\text { spesifik membahas } \\
\text { perempuan, karena dari } \\
\text { dulu dianggap tidak } \\
\text { masalah } \\
\text { - Isu peremp uan tidak } \\
\text { populer untuk dijual } \\
\text { - Basis PPP di desa (ibu-ibu } \\
\text { pengajian) }\end{array}$ & $\begin{array}{l}\text { - } \text { AD/ART partai } \\
\text { menyebutkan } \\
\text { keterwakilan } 30 \% \\
\text { perempuan. } \\
\text { - } \\
\text { Struktur partai : } \\
\text { dibentuk PPKB ( } \\
\text { Perempuan Partai } \\
\text { Kebangkitan Bangsa ) }\end{array}$ & $\begin{array}{l}\text { - Nominasi perempuan } \\
\text { dilakukan secara internal. } \\
\text { PKS } \\
\text { - Dewan pendirinya } \\
\text { melibatkan perempuan } \\
\text { - Perbidangan di pusat } \\
\text { dan provinsi dengan } \\
\text { nama Departemen } \\
\text { Kewanitaan PKS } \\
\text { - Memperhatikan kuota } 30 \\
\text { \% perempuan }\end{array}$ \\
\hline $\begin{array}{l}\text { - Sumbangan } \\
\text { untuk jadi caleg: } \\
\text { - } \text { DPRD II = 1 juta } \\
\text { - } \\
\text { DPRD I = } 5 \text { juta } \\
\text { - }\end{array}$ & $\begin{array}{l}\text { - Rekruitmen Kader: NU, SI, } \\
\text { PERTI, Muslimin } \\
\text { Indonesia, HMI, } \\
\text { Alwasiah, Muhamadiyah } \\
\text { (Karena PPP fusi dari } 4 \\
\text { kelompok tersebut) } \\
\text { - Membentuk lembaga } \\
\text { pendukung partai (WPP- } \\
\text { Wanita Persatuan } \\
\text { Pembangunan) } \\
\text { - Jujur dalam rekruitmen } \\
\text { dan nominasi perempuan } \\
\text { - Masalah:perempuan di } \\
\text { ormas pendukung selama } \\
\text { ini sulit masuk karena } \\
\text { dinamika konflik yang } \\
\text { tinggi, kurang transparan, } \\
\text { dan arena lobby serta } \\
\text { negosiasi yang sering } \\
\text { mengabaikan perempuan }\end{array}$ & 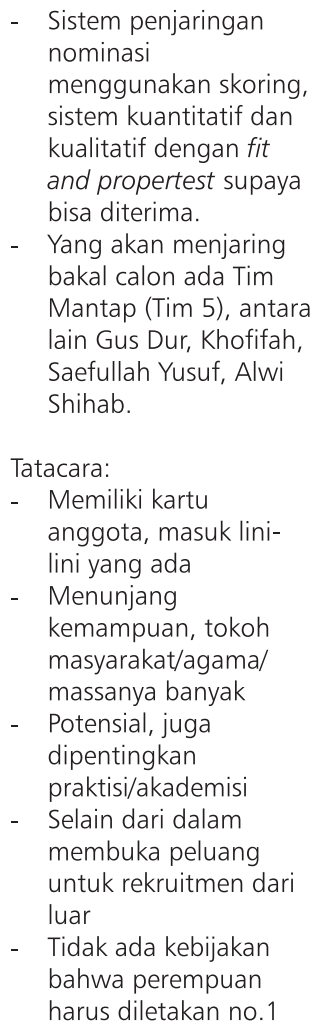 & $\begin{array}{l}\text { Seleksi Caleg: } \\
\text { - Pemilu Internal } \\
\text { - Caleg dibuka dari } \\
\text { kalangan kader partai }\end{array}$ \\
\hline
\end{tabular}

Penelitian ini juga berbeda dengan penelitian Krook yang mengungkap hambatan pemberlakuan kuota dari level institusional (wording, sistem pemilu) dan praktikal (kekuatan aktor yang mendukung dan menentang kuota), dan juga berbeda dengan penelitian Dahlerup yang mengungkap hambatan pemberlakuan kuota dari level institusional (sanksi kuota)

Argumen penulis dalam penelitian ini diharapkan dapat memberikan kontribusi teoritis dengan menunjukkan bahwa hegemoni pemaknaan (norma) liberal majoritarian dalam demokrasi dan perwakilan telah menjadi penghambat utama pemberlakuan kebijakan kuota perempuan karena norma tersebut melahirkan institusi (UU Parpol dan UU Pemilu) dan praktek politik yang tidak sesuai dengan kebutuhan kuota dan melanggengkan kekuasaan laki-laki dalam perpolitikan Indonesia (status quo). Dengan melihat 
pada aspek norma maka temuan ini dapat menyempurnakan teori serupa yang dikemukakan oleh Dahlerup dan Krook.

Menurut Mona Lena Krook, implementasi quota gender di sebuah negara dipengaruhi oleh tiga variabel utama yaitu variabel rincian mandat aturan atau undang-undang tentang quota itu sendiri, variabel kerangka institusional yang melingkupi quota tersebut dan variabel aktor atau kelompok yang mendukung dan menentang quota.

"The impact of quotas is linked to detail of the measures themselves, the impact of quota is depend on institutional framework in which they are introduces and the impact of quotas steams of the balance of actors for and against implementation" (Krooka, 2005: 42).

Sedangkan menurut Dahlerup, design kuota yang spesifik sangat menentukan keberhasilan pemberlakuan kuota "..the specific design of the quota system is crucial for the successful implementation of quotas". Artinya, design kuota harus memuat sanksi bagi partai yang tidak mematuhinya.

"in order to be effective, a quota system must be compatible with the electoral system in place and that quota rules - for example, of 30 or 40 per cent women on electoral lists - must be supplemented with rules concerning rank order as well as - in the case of legislated quotas effective legal sanctions"( Dahlerup and Freidenvall. 2008).

Baik Krook maupun Dahlerup tidak mengungkap aspek normative (ideology) yang mempengaruhi pembentukan institusi politik maupun perilaku actor dalam menanggapi kebijakan kuota perempuan.

Sementara penelitian ini menunjukkan bahwa mindset liberal dikalangan legeslatif (pembuat undang-undang, pimpinan partai), yudikatif (hakim konstitusi). maupun aktivis pro demokrasi Indonesia yang menekankan perpolitikan pada level individual, memaknai kesetaraan sebagai equal opportunity dan memaknai keadilan sebagai distributive justice telah menjadi penghambat kebijakan kuota, baik pada tahap perumusan maupun pemberlakuan.
Efektifitas pemberlakuan kuota perempuan bukan hanya ditentukan oleh variable wording, institusional (system pemilu), sanksi maupun kekuatan actor yang mendukung kuota seperti dikatakan oleh Krook, Dahlerup maupun Wahidah br Siregar, namun juga dipengaruhi oleh ideology yang berkembang di Negara tersebut. Bahkan aspek ideology akan menentukan perumusan wording ketentuan kuota, kerangka institusional (system pemilu), kebijakan partai maupun perilaku aktor dalam merespon kebijakan kuota. Aspek ideology inilah yang membedakan efektifitas pemberlakuan kuota perempuan di beberapa Negara Scandinavia-Amerika Latin-Australia, Rwanda (demokrasi sosial-demokrasi konsosiasional) dan Indonesia-Amerika Serikat (demokrsi liberal majoritarian).

Di Negara yang mengalami demokratisasi seperti di Indonesia kebijakan kuota diambil selain karena desakan gerakan perempuan yang sangat kuat juga sebagai upaya untuk menunjukkan bahwa Negara tersebut demokratis. Keberadaan ketentuan kuota bukan berarti merupakan jaminan peningkatan keterwakilan perempuan karena mindset liberal memaksa perempuan untuk bersaing dengan mengandalkan kekuatan individualnya dan aturan main didesign dengan prinsip equal opportunity, OPOVOV dan surat suara tunggal (single ballot) serta meritokrasi.

Penelitian ini mengkonfirmasi pendapat Anne Phillip dan beberapa ilmuwan feminist lainnya bahwa teori-teori demokrasi liberal tidak netral gender (Phillip, 1991). Pembahasan pada bab-bab terdahulu menunjukkan bahwa norma, institusi (system dan teknis pemilu) dan praktek yang terkait dengan demokrasi dan perwakilan politik di Indonesia tersebut tidak netral, melainkan sarat dengan kepentingan politik. Ketimpangan gender dalam lembaga perwakilan yang terjadi secara terus menerus merupakan salah satu bukti dari ketidaknetralan tersebut. Fakta ini membenarkan pernyataan Critical Theory bahwa teori juga tidak bersifat netral tetapi cenderung menguntungkan pihak yang kuat dan melanggengkan status quo. Gagasan kuota perempuan 
merupakan terobosan pemikiran alternative yang bersifat emansipatoris.

Pengalaman di berbagai negara seperti Rwanda, Inggris, Canada, New Zealand, India dan lain-lain menunjukkan bahwa keberhasilan peningkatan keterwakilan perempuan selalu didahului dengan electoral engineering (perekayasaan system pemilu) atau lebih tepatnya reformasi/inovasi sistem dan teknis pemilu yang memberikan peluang lebih besar bagi perempuan untuk terpilih. Electoral engineering dilakukan dengan membuat inovasi teknis pemilu yang pro perempuan.Inovasi tersebut dilakukan oleh Rwanda dengan memperkenalkan Triple balloting system, Inggris memperkenalkan All women's short lists', Afganistan memperkenalkan reserved seats melalui pemilihan secara langsung, India memperkenalkan Dual-member Constituencies di Lok Sabha (masih dalam tahap usulan) dan Twinning System di Scottist yang terbukti mampu memberikan akselerasi terhadap kebijakan kuota perempuan.

Partisipasi perempuan dalam lembaga demokrasi Indonesia berada dibawah tekanan dan dominasi norma-norma liberal. Perempuan adalah salah satu dari kelompok minoritas seperti orang tua (lansia), minoritas etnik dan kelompok masyarakat miskin yang dihambat untuk mengekspresikan pengalamannya dalam realitas politik karena liberal selalu memaksakan norma homogeneity, impartiality dan rationality. Norma liberal yang menekankan impartiality, generality dan formal equality cenderung merugikan perempuan karena keyakinan akan norma-norma tersebut menjadikan liberal tidak mampu mengakomodasi perbedaan-perbedaan dan particularitas yang ada di masyarakat, termasuk fakta akan adanya perbedaan aktifitas antara perempuan dan laki-laki. Akibatnya, norma-norma liberal tentang demokrasi dapat menjadi sarana dominasi politik laki-laki atas perempuan.

Karena masing-masing kelompok mempunyai pengalaman, sejarah dan cara pandang yang berbeda terhadap kehidupan sosial maka tidak ada satupun kelompok yang dapat mewakili pengalaman, sejarah dan cara pandang dari kelompok lain. Dalam menghadapi keberagaman kelompok-kelompok tersebut, maka penggunaan norma formal equality dan impartiality hanya akan menguntungkan kelompok dominan (laki-laki). Jika semua individu diberi hak yang sama (equal right), maka kepentingan dari kelompok dominanlah yang akan berlaku karena mereka akan menyatakan bahwa pengalaman dan cara pandang mereka tentang realitas social sebagai suatu hal yang obyektif dan tidak memihak. Artinya, norma kelompok dominan (laki-laki) lah yang menjadi standar. Atas nama obyektifitas dan ketidakberpihakan (impartiality) maka kelompok-kelompok minoritas, termasuk perempuan, menjadi terpinggirkan dalam kehidupan politik. Atas nama universalism maka norma-norma asli yang dipunyai oleh kelompokkelompok minoritas, termasuk perempuan, menjadi terdegradasi. Sebaliknya, norma laki-laki menjadi standar.

\section{CATATAN AKHIR}

$1 \quad$ Ketiadaan ideologi yang berperan sebagai counter hegemoni ini membedakan pengaruh norma liberal di Indonesia dengan negaranegara Amerika Latin (Argentina) dan negara-negara dengan tradisi demokrasi yang kuat seperti Scandinavia, Inggris, Australia, Selandia Baru, Inggris, Selandia Baru, Skandinavia, Belanda, Swiss dan Belgia.

2 Penolakan gagasan kuota perempuan atas dasar norma demokrasi bukan hanya terjadi di Indonesia. Atas nama prinsip-prinsip demokrasi ini pulalah Amerika Serikat yang menjadi pemimpin Coalition Provisional Authority (CPA) setelah kejatuhan Sadham Hussein di Irak, menentang usulan organisasi-organisasi perempuan Irak yang menginginkan kuota 30\% di parlemen lokal, nasional, kabinet dan Komisi Pembuat Konstitusi. Penolakan Amerika ini dijawab dengan mobilisasi perempuan Irak sehingga akhirnya CPA memenuhi tuntutan perempuan. Atas nama norma demokrasi pula Amerika Serikat hingga saat ini tidak mengadopsi kuota perempuan meski tingkat keterwakilan politik perempuan di Comgres hanya $16,9 \%$ dan di Senate hanya 17\%3. Alasan yang sama digunakan oleh Mahkamah Konstitusi Perancis yang pada tahun 1982 menganulir peraturan kuota gender (25\%-75\%) karena kuota sex dianggap bertentangan dengan dengan prinsip republikan tentang equality dan mengancam bagi demokrasi Perancis. Jelas bahwa konflik normative, meski tidak kasat mata, menjadi hambatan bagi pemberlakuan kuota perempuan diberbagai Negara.

4 Dilihat dari proses bekerjanya, demokrasi dapat dibedakan dalam tiga model, yaitu Model Aggregative, Model Deliberative dan Model Anti Dominasi

5 Diolah dari CETRO

\section{REFERENSI}

Cook, Guy. 1994. The Discourse of Advertising. London and New York: 
Routledge.

Dahlerup, Drude and Lenita Freidenvall. 2008. Electoral Gender Quota Systems and Their Implementation in Europe. WIP, Women in Politics Research Centre, Department of Political Science, Stockholm University in cooperation with International IDEA

Eriyanto. 2009. Analisis Wacana: Pengantar Analisis Teks Media. Cetakan VII. Yogyakarta: LKiS.

Kitschelt, Herbert and Steven Wilkinson. 2007. Patrons, Clients, and Policies: Patterns of Democratic Accountability and Political Competition. Cambridge: Cambridge University Press.

Kitschelt. 2000. Linkages between citizens and politicans in democratic politics. Comparative Political Studies 33 (6/7)

Krook, Mona Lena, 2005. Politizing Representation: Campaign for Candidate Gender Quotas Worlwide. Columbia University

Krooka, Mona Lena and Judith Squires. 2006. Gender Quotas in British Politics: Multiple Approaches and Methods in Feminist Research. Palgrave Macmillan Ltd. (Online), (www. palgrave-journals.com/bp)

Phillip, Anne. 1991. Engendering Democracy. Cambridge, UK: Polity Press.

Pirages, Dennis dan Christine Sylvester (ed). 1989. Transformations in the Global Political Economy. Basingstoke: Macmillan.

Smooha, Sammy. 2001. The Model of Ethnic Democracy. ECMI Working Paper, 13 October. European Centre for Minority Issues (ECMI) Schiffbruecke 12 (Kompagnietor Building) Flensburg Germany. (Online), (http://www.ecmi.de)

Soetjipto, Ani. 2009. Dampak Diterapkannya Aturan Suara Terbanyak terhadap Keterwakilan Perempuan dan Gerakan Perempuan. Jakarta: Women Research Institute.

Women in National Parliament. (Online), (http://www.ipu.org) 